\title{
IMPLEMENTASI UNDANG-UNDANG NO. 3 TAHUN 1997 TENTANG PENGADILAN ANAK (Studi terhadap Anak yang Berhadapan dengan Hukum dalam Tingkat Penyidikan di Polres Purbalingga)
}

\author{
Mugiman \\ Divisi Advokasi Kepolisian Daerah, Semarang, Jawa Tengah
}

\begin{abstract}
In investigating a case involving child, the police always prioritized the child's interest as the basis of handling the case and tried its best to avoid bringing the case to trial. The employed the penal and non penal approach. The non penal approach was done through diverting and restorative justice method. The diverting method was meant to eliminate the negative effect which might result from legal proceeding, and replaced it with a discretion which was based its function as public service provider. The police did this by aborting the legal process and returning the child to the parents or replacing with other form of obligation for the child to give social service. The impending factors in this implementation was that there had not been common perception among the police officers as the law enforcing body due to their lack of understanding of the spirit of the law. Besides that there was also the constraint due to lack of public service facilities and society's lack of concern towards their neighborhood and tendency to judge child behavior as the same as that of the adults.
\end{abstract}

Keywords : juvenile, penal approach, non penal approach

\begin{abstract}
Abstrak
Dalam menyelidiki kasus yang melibatkan anak, polisi selalu memprioritaskan kepentingan anak sebagai dasar penanganan kasus ini dan mencoba yang terbaik untuk menghindari membawa kasus ini ke pengadilan. pendekatan ini yang digunakan dengan menggunakan pendekatan penal maupun non penal. Pendekatan pena tidak dilakukan melalui metode mengalihkan dan keadilan restoratif. Metode pengalihan dimaksudkan untuk menghilangkan efek negatif yang mungkin timbul dari proses hukum, dan menggantinya dengan kebijaksanaan yang didasarkan fungsinya sebagai penyedia pelayanan publik. Polisi melakukan hal ini dengan membatalkan proses hukum dan kembali anak untuk orang tua atau mengganti dengan bentuk lain kewajiban bagi anak untuk memberikan pelayanan sosial. Faktorfaktor yang akan datang dalam pelaksanaan ini adalah bahwa tidak ada persepsi umum di antara polisi sebagai penegak hukum tubuh karena kurangnya pemahaman tentang semangat hukum. Selain itu ada juga kendala karena kurangnya fasilitas pelayanan publik dan kurangnya kepedulian masyarakat terhadap lingkungan dan kecenderungan untuk menilai perilaku anak sebagai sama dengan orang dewasa.
\end{abstract}

Kata kunci : anak nakal, pendekatan penal, pendekatan non penal

\section{Pendahuluan}

Dikemukakan oleh Kartini Kartono, bahwa gangguan masa remaja dan anak-anak, yang disebut sebagai chilhood disorders dan menimbulkan penderitaan emosional minor serta gangguan kejiwaan lain pada pelakunya, di kemudian hari bisa berkembang jadi bentuk kejahatan remaja (Juvenile Delinquency). Kejahatan yang dilakukan oleh anak-anak muda remaja pada intinya merupakan produk dari kondisi masyarakatnya dengan segala pergolaan yang ada di dalamnya. Kejahatan anak remaja ini disebut sebagai salah satu penyakit masyarakat atau penyakit sosial. ${ }^{1}$

Menurut Wagiati Soetodjo, bahwa Juvenile Delinquency adalah suatu tindakan atau perbuatan pelanggaran norma, baik norma hukum maupun norma sosial yang dilakukan

\footnotetext{
1 Kartini Kartono, 1992, Patologi Sosial 2 Kenakalan Remaja, Jakarta: Rajawali Pers, hlm. 4
} 
oleh anak-anak usia muda. Hal tersebut cenderung untuk dikatakan sebagai kenakalan anak dari pada kejahatan anak, terlalu ekstrim rasanya seorang anak yang melakukan tindak pidana dikatakan sebagai penjahat, sementara kejadiannya adalah proses alami yang tidak boleh tidak setiap manusia harus mengalami kegoncangan semasa menjelang kedewasaannya. ${ }^{2}$

Dijelaskan dalam Penjelasan Umum UU No. 3 Tahun 1997, bahwa dalam menghadapi dan menanggulangi berbagai perbuatan dan tingkah laku anak nakal, perlu dipertimbangkan kedudukan anak dengan segala ciri dan sifatnya yang khas. Walaupun anak telah dapat menentukan sendiri langkah perbuatannya berdasarkan pikiran, perasaan, dan kehendaknya, tetapi keadaan sekitarnya dapat mempengaruhi perilakunya. Oleh karena itu, dalam menghadapi masalah anak nakal, orang tua dan masyarakat sekelilingnya harus lebih bertanggung jawab terhadap pembinaan, pendidikan dan pengembangan perilaku anak tersebut.

Dalam praktik penegakan hukum terhadap penanganan kasus tindak pidana yang di lakukan oleh anak di wilayah hukum Polres Purbalingga pada tahun 2007 sampai dengan 2009 dapat dilihat pada tabel 1.

Melihat data tersebut, dapat diketahui bahwa terhadap semua perkara tindak pidana yang dilakukan oleh anak pada tahun 2007 sampai pada bulan Agustus 2009 yang ditangani oleh Polres Purbalingga ternyata dalam penanganan kasusnya tidak semua kasus tindak pidana yang dilakukan oleh anak dilimpahkan ke Kejaksaan tetapi ada juga yang diselesaikan secara perdamaian oleh para pihak yang bersangkutan.

Undang-undang Pengadilan Anak telah meletakan dasar perbedaan perlakuan dalam menghadapi dan menyelesaikan tindak pidana yang dilakukan oleh anak, dengan tujuan pembedaan tersebut untuk lebih melindungi dan mengayomi anak agar dapat menyongsong masa depannya yang masih panjang. Selain itu pembedaan tersebut dimaksudkan untuk memberi kesempatan kepada anak agar melalui pem-

\footnotetext{
2 Wagiati Soetodjo, 2006. Hukum Pidana Anak. Bandung:
} Refika Aditama,hlm. 12 binaan akan memperoleh jati dirinya untuk menjadi manusia yang mandiri, bertanggung jawab, dan berguna bagi diri, keluarga, masyarakat, bangsa, dan negara.

\section{Tabel 1}

Data kasus yang diproses maupun yang tidak diproses, Diversi dan Diskresi tahun 2007 - 2009 Polres Purbalingga

\begin{tabular}{|c|c|c|c|c|c|c|c|c|c|}
\hline \multirow[b]{2}{*}{ Kasus } & \multicolumn{3}{|c|}{$\begin{array}{l}\text { Tahun } \\
2007\end{array}$} & \multicolumn{3}{|c|}{$\begin{array}{l}\text { Tahun } \\
2008\end{array}$} & \multicolumn{3}{|c|}{$\begin{array}{c}\text { Tahun } \\
2009\end{array}$} \\
\hline & $\begin{array}{l}\mathrm{P} \\
\mathrm{r} \\
\mathrm{o} \\
\mathrm{s} \\
\mathrm{e} \\
\mathrm{s}\end{array}$ & $\begin{array}{l}\text { D } \\
\text { I } \\
\text { v } \\
\text { e } \\
r \\
s \\
\text { l }\end{array}$ & $\begin{array}{l}\text { D } \\
\text { l } \\
\text { s } \\
\text { k } \\
\text { r } \\
\text { e } \\
\text { s } \\
\text { i }\end{array}$ & $\begin{array}{l}P \\
r \\
o \\
s \\
e \\
\text { S }\end{array}$ & $\begin{array}{l}\text { D } \\
\text { I } \\
\text { v } \\
\text { e } \\
\text { r } \\
\text { s } \\
\text { i }\end{array}$ & $\begin{array}{l}\text { D } \\
\text { l } \\
\text { s } \\
\text { k } \\
\mathrm{r} \\
\mathrm{e} \\
\mathrm{s} \\
\mathrm{i}\end{array}$ & $\begin{array}{l}P \\
r \\
o \\
\text { s } \\
\text { e } \\
\text { S }\end{array}$ & $\begin{array}{l}\text { D } \\
\text { I } \\
\text { v } \\
\text { e } \\
\text { r } \\
\text { s } \\
\text { i }\end{array}$ & $\begin{array}{l}\text { D } \\
\text { l } \\
\text { s } \\
\text { k } \\
\mathrm{r} \\
\mathrm{e} \\
\mathrm{s} \\
\mathrm{i}\end{array}$ \\
\hline Pemerkosaan & 1 & - & - & - & - & - & - & - & - \\
\hline $\begin{array}{l}\text { Memaksa } \\
\text { anak untuk } \\
\text { melakukan } \\
\text { persetubuhan }\end{array}$ & 2 & - & 1 & - & - & - & - & 2 & 2 \\
\hline $\begin{array}{l}\text { Perbuatan } \\
\text { cabul }\end{array}$ & - & - & - & - & - & - & - & - & 1 \\
\hline Pengeroyokan & - & - & 1 & - & - & - & - & - & 1 \\
\hline $\begin{array}{l}\text { Pencurian } \\
\text { dengan } \\
\text { pemberatan }\end{array}$ & - & - & 1 & - & - & - & - & - & - \\
\hline $\begin{array}{l}\text { Pencurian } \\
\text { biasa }\end{array}$ & - & - & 1 & - & - & - & - & - & - \\
\hline Jumlah & 3 & - & 4 & - & - & - & - & 2 & 2 \\
\hline
\end{tabular}

Sumber : PPA Polres Purbalingga, Desember 2009

Berdasarkan uraian sebagaimana tersebut di atas, penulis tertarik untuk melakukan kajian secara yuridis tentang implementasi UU No. 3 Tahun 1997 tentang Pengadilan Anak dalam praktik penanganan anak Delinquent, penelitian dilakukan terhadap anak yang berhadapan dengan hukum dalam tingkat penyidikan di wilayah hukum Polres Purbalingga.

\section{Permasalahan}

Artikel ini hendak membahas dua permasalahan. Pertama, berkaitan dengan implementtasi Undang-Undang No. 3 Tahun 1997 terhadap anak yang berhadapan dengan hukum dalam tingkat penyidikan di Polres Purbalingga; dan kedua, mengenai faktor-faktor yang menghambat implementasi Undang-Undang No. 3 Tahun 1997 terhadap anak yang berhadapan dengan hukum dalam tingkat penyidikan di Polres Purbalingga. 


\section{Metode Penelitian}

Penelitian ini merupakan penelitian yuridis sosiologis dengan sifat deskriptif sebagai spesifikasi penelitian. Sumber datanya berupa data primer yang diperoleh melalui wawancara dan data sekunder yang diperoleh melalui studi pustaka. Lokasi penelitian terletak di Polres Purbalingga. Data yang diperoleh disajikan dalam bentuk uraian yang disusun secara sistematis, logis, dan rasional dan dianailis dengan analisis kualitatif.

\section{Hasil Penelitian dan Pembahasan}

Implementasi UU No. 3 Tahun 1997 terhadap Anak yang Berhadapan dengan Hukum dalam Tingkat Penyidikan di Polres Purbalingga

Menurut Kamus Umum Bahasa Indonesia yang disusun oleh W.J.S Poerwadarminta, bahwa yang dimaksud dengan pengertian implementtasi adalah pelaksanaan. ${ }^{3}$ Berbicara mengenai implementasi UU No. 3 Tahun 1997 terhadap anak yang berhadapan dengan hukum dalam tingkat penyidikan, berarti berbicara pula tentang penerapan atau pelaksanaan hukum.

Sejalan dengan pokok permasalahan yang diajukan, maka dalam pembahasan atau analisis ditekankan pada implementasi bekerjanya lembaga penegak hukum yang dalam hal ini adalah Kepolisian (Polres Purbalingga) sebagai salah satu lembaga atau organisasi/birokrasi penegak hukum dalam bidang penyidikan.

Kepolisian adalah merupakan suatu bentuk organisasi penegak hukum, dan apabila berbicara mengenai organisasi maka satu hal yang pokok adalah bagaimana organisasi itu akan "dibuat berjalan". Proses ini tidak lain merupakan kegiatan manajemen. Manajemen menurut Shorde dan Voich diartikan sebagai perangkat kegiatan atau suatu proses untuk mengkordinasi atau mengkoordinasikan penggunaan sumbersumber daya dengan tujuan untuk mencapai tujuan organisasi melalui orang-orang, teknikteknik dan informasi dan dijalankan dalam kerangka suatu struktur organisasi. ${ }^{4}$

\footnotetext{
W.J.S. Porwadarminta, 1991. Kamus Umum Bahasa Indonesia. Jakarta: Balai Pustaka, hlm. 377

4 Satjipto Rahardjo, Tanpa tahun. op. cit. hlm. 16
}

Tujuan dari setiap organisasi adalah untuk mencapai sasaran-sasaran yang dikehendaki dengan kualifikasi produktivitas serta kepuasan, atau gabungan dari keduanya, tergantung dari kegiatan yang dijalankan oleh organisasi yang bersangkutan, dalam hal ini Kepolisian (Polres Purbalingga). Untuk mencapai tujuan tersebut maka unsur-unsur organisasi itu di operasionalkan, yang memaparkan diri dalam wujud bergeraknya organisasi tersebut. Aktivitas untuk mengkoordinasi unsur-unsur tersebut disebut sebagai pengelolaan organisasi. Aktivitas inilah yang bertanggung jawab terhadap karya, pertumbuhan dan kelangsungan hidup organisasi. Selama organisasi itu bekerja ia berhadapan pula dengan masalah lingkungan yang harus diterima dan diperhitungkan, berupa lingkungan-lingkungan sosial, politik, manusia, ekonomi serta teknologi. ${ }^{5}$

Kegiatan manajemen yang dijalankan oleh Polres Purbalingga terkait dengan implementasi Undang-undang No. 3 Tahun 1997 terhadap anak yang berhadapan dengan hukum dalam tingkat penyidikan digunakan teori yang dikemukakan oleh Robert B. Seidman, yaitu teori bekerjanya hukum yang pada pokoknya dikatakan bahwa "Bagaimana suatu lembaga penegak hukum itu akan bekerja sebagai respons terhadap peraturan-peraturan hukum, merupakan fungsi dari peraturan yang ditujukan kepadanya, sanksi-sanksinya, keseluruhan kompleks dari kekuatan-kekuatan sosial, politik, dan lain-lain yang bekerja atasnya, dan umpan balik yang datang dari para pemegang peran (role accupants).

Mengenai proses bekerjanya hukum dalam masyarakat dijelaskan dengan teori yang dikemukakan oleh Robert B. Siedman. Dalam teori tersebut terdapat tiga komponen utama pendukung bekerjanya hukum dalam masyarakat. Ketiga komponen tersebut meliputi (1) Lembaga pembuat peraturan; (2) Lembaga penerap peraturan; dan (3) Pemegang peran. Dari ketiga komponen dasar tersebut Robert $B$. Seidman mengajukan beberapa dalil sebagai berikut.

\footnotetext{
5 Ibid., hlm. 70
} 
Pertama, setiap peraturan hukum memberitahu tentang bagaimana seorang pemegang peran diharapkan bertindak. Kedua, bagaimana seseorang pemegang peran itu akan bertindak sebagai suatu respon terhadap peraturan hukum merupakan fungsi peraturan-peraturan yang ditujukan kepadanya, sanksi-sanksinya, aktivitasnya dari lembaga pelaksana serta keseluruhan kompleks sosial, politik dan lainlainnya mengenai dirinya. Ketiga, bagaimana lembaga-lambaga pelaksana itu akan bertindak sebagai respon terhadap peraturan-peraturan hukum merupakan fungsi peraturan-peraturan hukum yang ditujukan, sanksi-sanksinya, keseluruhan kompleks kekuatan sosial, politik dan lain-lainnya yang mengenai diri mereka serta umpan-umpan balik yang datang dari para pemegang peran. Keempat, bagaimana pembuat undang-undang itu akan bertindak merupakan fungsi peraturan-peraturan yang mengatur tingkah laku mereka, sanksi-sanksi, keseluruhan kompleks kekuatan-kekuatan sosial, politik, ideologi dan lain-lainnya yang menganai diri mereka serta umpan balik yang datang dari pemegang peran serta birokrasi. ${ }^{6}$

Berdasarkan pendapat yang dikemukakan oleh Robert B. Seidman sebagaimana tersebut dalam bagan di atas tentang birokrasi penegak hukum dan lingkungannya, maka dapat dijelaskan bahwa realitas bekerjanya organisasi Kepolisian (Polres Purbalingga) yaitu mengkoordinasikan penggunaan sumber-sumber daya untuk mencapai tujuan organisasi melalui orang-orang, teknik-teknik dan informasi yang dijalankan dalam kerangka suatu struktur organisasi, dalam melaksanakan fungsi/tugas dan kewenangan dimaksud yaitu implementasi UU No. 3 Tahun 1997 terhadap anak yang berhadapan dengan hukum dalam tingkat penyidikan dijalankan dengan mengikuti dan memenuhi berbagai pembatasan yang ditentukan oleh patokan-patokan formal berupa peraturanperaturan hukum yang berkaitan dengan masalah anak yang sedang berurusan dengan hukum.

Berkaitan dengan fungsi/tugas dan kewenangan dimaksud yaitu implementasi UU No. 3

\footnotetext{
6 Satjipto Rahardjo, 1980, Hukum dan Masyarakat, Bandung: Alumni, hlm. 27
}

Tahun 1997 terhadap anak yang berhadapan dengan hukum dalam tingkat penyidikan, pelaksanaan tugas Polri sebagaimana telah di sebutkan dalam ketentuan Pasal 2 Undang-Undang Nomor 2 Tahun 2002 Tentang Kepolisian Negara Republik Indonesia yaitu fungsi kepolisian adalah salah satu fungsi pemerintahan Negara di bidang pemeliharaan keamanan dan ketertiban masyarakat, penegakan hukum, perlindungan, pengayoman, dan pelayanan kepada masyarakat.

Substansi tugas pokok memelihara keamanan dan ketertiban masyarakat bersumber dari kewajiban umum kepolisian untuk menjamin keamanan umum. Sedangkan substansi tugas pokok menegakkan hukum bersumber dari ketentuan peraturan perundang-undangan yang memuat tugas pokok Polri dalam kaitannya dengan peradilan pidana, contoh KUHP, KUHAP dan berbagai Undang-Undang tertentu lainnya. Selanjutnya substansi tugas pokok Polri untuk memberikan perlindungan, pengayoman dan pelayanan kepada masyarakat bersumber dari kedudukan dan fungsi Kepolisian sebagai bagian dari fungsi pemerintahan negara yang pada hakekatnya bersifat pelayanan publik (public service) yang termasuk dalam kewajiban umum kepolisian. $^{7}$

Menurut Pudi Rahardi, tugas penyelidikan dan penyidikan yang harus dilaksanakan oleh penyelidik dan penyidik (Pejabat Polri atau menurut istilah KUHAP "Pejabat Polisi Negara Republik Indonesia) meliputi kegiatan mencari dan menemukan suatu peristiwa yang diduga sebagai tindak pidana; menentukan dapat atau tidaknya dilakukan penyidikan; mencari serta mengumpulkan bukti; membuat terang tentang tindak pidana yang terjadi; dan menentukan tersangka pelaku tindak pidana. ${ }^{8}$

Penyidikan yang merupakan kontak awal antara anak yang berhadapan dengan hukum $(\mathrm{ABH})$ dengan pihak Kepolisian sangat tepat memberikan penekanan pentingnya memperhatikan prinsip-prinsip penanganan pada tingkat penyidikan sebagaimana diatur dalam ke-

\footnotetext{
7 Pudi Rahardi, 2007, op. cit. hlm. 68

8 Ibid., hlm. 71
} 
tentuan Pasal 1 butir 5, 6, 7, 8 dan 9 UU No. 3 Tahun 1997.

Dalam penyidikan terhadap anak yang bermasalah dengan hukum $(\mathrm{ABH})$ yang dilakukan oleh Polres Purbalingga adalah sesuai dengan ketentuan yang telah diatur UU No. 3 Tahun 1997 sebagaimana dirumuskan dalam ketentuan Pasal 34, Pasal $41 \mathrm{~s} / \mathrm{d}$ Pasal 45 dan Pasal 51, Pasal 52. Berdasarkan pasal-pasal sebagaimana tersebut di atas, pada dasarnya penyidikan anak khususnya mereka yang sedang menghadapi masalah hukum, sesuai dengan pendapat yang dikemukakan oleh Yahya Harahap bahwa "penyelidikan" merupakan tindakan tahap pertama atau permulan "penyidikan". Akan tetapi harus diingat, penyelidikan bukan tindakan yang berdiri sendiri terpisah dari fungsi "penyidikan". Penyelidikan merupakan bagian yang tak terpisahkan dari fungsi penyidikan. Kalau dipinjam kata-kata yang dipergunakan dalam buku petunjuk Pedoman Pelaksanaan KUHAP, penyelidikan "merupakan salah satu cara atau metode atau sub daripada fungsi penyidikan yang mendahului tindakan lain, yaitu penindakan yang berupa penangkapan, penahanan, penggeledahan, penyitaan, pemeriksaan surat, pemanggilan, tindakan pemeriksaan, dan penyerahan berkas kepada penuntut umum". ${ }^{9}$

Penyidikan terhadap anak nakal dilakukan oleh penyidik anak, yang diterapkan berdasarkan Surat Keputusan Kepala Kepolisian Republik Indonesia atau pejabat yang ditunjuk olehnya. Dengan demikian penyidik umum tidak dapat melakukan penyidikan atas perkara anak nakal, kecuali dalam hal-hal tertentu, seperti belum adanya penyidik anak ditempat tersebut. Syarat-syarat untuk menjadi penyidik anak, sesuai dengan ketentuan Pasal 41 ayat (2) UU No. 3 Tahun 1997 adalah : a) telah berpengalaman sebagai penyidik; dan b) mempunyai minat, perhatian, desikasi, dan memahami masasalah anak.

Penyidikan terhadap anak berlangsung dalam suasana kekeluargaan, dan untuk itu penyidik meminta pertimbangan atau saran dari

\footnotetext{
9 Yahya Harahap, 2005, op.cit. hlm . 101
}

Pembimbing Kemasyarakatan sesuai dengan ketentuan Pasal 42 Undang-undang Pengadilan Anak. pemeriksaan dalam suasana kekeluargaan berarti pada waktu memeriksa tersangka, penyidik tidak memakai pakaian dinas, dan melakukan pendekatan-pendekatan secara efektif, aktif dan simpatik, tidak ada pemaksaan, intimidasi atau sejenisnya selama penyidikan. ${ }^{10}$

Berdasarkan penjelasan di atas, apabila dipandang perlu penyidik juga meminta pertimbangan atau saran dari ahli pendidikan, ahli kesehatan, ahli jiwa, ahli agama, atau petugas kemasyarakatan lainnya. Untuk kepentingan anak, proses penyidikan wajib dirahasiakan ( $\mathrm{Pa}$ sal 42 ayat (3), hal ini dimaksudkan agar anak terhindar dari depresi, rasa malu yang akhirnya sukar untuk diterima kembali dilingkungannya.

\section{Tahap Penangkapan}

Dalam ketentuan Pasal 1 butir 20 KUHAP, penangkapan adalah suatu tindakan penyidik berupa pengekangan kebebasan sementara waktu tersangka atau terdakwa apabila terdapat cukup bukti guna kepentingan penyidikan atau penuntutan dan atau peradilan dalam hal serta menurut cara yang diatur dalam undangundang ini.

Penangkapan merupakan ketentuan Hukum Acara Pidana yang menjadi sorotan esensial dari proses penyidikan. Tugas penangkapan berbatasan dengan ketentuan hukum yang menegakan hak-hak asasi anak yang dapat menjadi tuntutan keadilan hukum terhadap petugas penegakan hukum dari pemerintah yang dalam hal ini adalah lembaga kepolisian.

Dalam Pasal 17 KUHAP menentukan bahwa perintah penangkapan dilakukan terhadap seorang yang diduga keras melakukan tindak pidana berdasarkan bukti permulaan yang cukup. Adapun penangkapan hanya dapat dilakukan untuk paling lama satu hari (Pasal 19 KUHAP dan Pasal 43 ayat (2) Undang-undang Pengadilan Anak). Menurut ketentuan Pasal 43 ayat (1) Undang-undang No. 3 Tahun 1997, penangkapan terhadap anak nakal dilakukan sesuai dengan KUHAP, dengan demikian proses penangkapan

\footnotetext{
${ }^{10}$ Darwan Prinst, 1993, Praperadilan dan Perkembangan di dalam Praktik. Bandung: Citra Aditya Bakti. hlm. 38
} 
anak nakal adalah sama dengan proses penangkapan orang dewasa sebagaimana ditentukan dalam KUHAP.

Penangkapan yang dilakukan oleh petugas Polri dengan memperlihatkan surat tugas serta memberikan surat perintah penangkapan tersebur dengan mencantumkan identitas tersangka dan menyebutkan alasan penangkapan serta urraian singkat kejahatan yang dipersangkakan serta tempat ia akan diperiksa (Pasal 18 ayat (1) KUHAP). Dalam hal tertangkap tangan, penangkapan dapat dilakukan tanpa surrat perintah, dengan ketentuan bahwa penangkap harus segera menyerahkan tertangkap tangan beserta barang bukti yang ada kepada penyidik atau penyidik pembantu terdekat (Pasal 18 ayat (2) KUHAP). Ketentuan ini berlaku pula untuk melakukan penangkapan terhadap tersangka pelaku anak.

Syarat-syarat untuk melakukan penangkapan dibagi dua, yaitu syarat formal dan syarat materiil, syarat-syarat tersebut adalah dilakukan oleh penyidik Polri atau penyelidik atas perintah penyidik; dilengkapi dengan surat pperintah penangkapan dari penyidik; menyerahkan surat perintah penangkapan kepada tersangka dan tembusannya disampaikan kepada keluarganya. Syarat-syarat materiil antara lain ada bukti permulaan yang cukup (Pasal 17 KUHAP); penangkapan dilakukan paling lama 1 x 24 jam. Penangkapan yang tidak melalui syarat di atas adalah tidak sah dan karenanya dapat diajukan praperadilan untuk menyatakan ketidaksahannya sekaligus menintakan ganti kerugian atas penangkapan itu. ${ }^{11}$

\section{Tahap Penahanan}

Dalam ketentuan Pasal 1 butir 21 KUHAP memberikan pengertian tentang penahanan yaitu penempatan tersangka atau terdakwa di tempat tertentu oleh penyidik, atau penuntut umum, atau hakim dengan penempatannya, dalam hal serta menurut cara yang diatur dalam undang-undang ini. Ketentuan tentang sahnya penahanan sebagaimana tercantum dalam Pasal 21 ayat (4) KUKAP, yaitu penahan-

\footnotetext{
${ }^{11}$ Darwan Prinst, 1993, op. cit. hlm. 15
}

an tersebut hanya dapat dilaksanakan terhadap tersangka yang melakukan tindak pidana dan atau percobaan maupun pemberian bantuan dalam tindak pidana tersebut dalam hal: 1) tindak pidana itu diancam dengan pidana lima tahun atau lebih; 2) tindak pidana tertentu lainnya yang diancam dengan pidana penjara kurang dari lima tahun.

Masa penahanan untuk tiap-tiap tingkat peemeriksaan mulai dari penyidikan, penuntutan, pemeriksaan di pengadilan, dibatasi secara limitatif oleh undang-undang, oleh karena itu petugas yang melakukan penahanan tidak dapat sewenang-wenang melakukan penahanan.

Penahanan terhadap anak hanya dapat dilakasanakan setelah sungguh-sungguh mempertimbangkan kepentingan anak atau masyarakat. Penahanan terhadap anak, juga harus memperhatikan kepentingan anak yang menyangkut pertumbuhan dan perkembangan anak, baik fisik, maupun mental sosial anak dan kepentingan masyarakat. Oleh karena itu alasan penahanan harus dinyatakan secara tegas dalam surat perintah penahanan. Tempat penahanan anak harus dipisahkan dengan tempat penahanan untuk orang dewasa, dan selama penahanan kebutuhan jasmani, rokhani, dan sosial anak harus tetap terpenuhi.

Dalam menangani anak yang berhadapan dengan hukum dalam tingkat penyidikan, penyidik terus berupaya mencari alternatif penyelesaian terbaik bagi kepentingan anak serta berupaya menjauhkan anak dari proses peradilan formal. Untuk merealisasikan hal tersebut penggunaan wewenang diskresi tidak dapat dilepaskan dari pelaksanaan penegakan hukum dan ketertiban masyarakat. Wewenang diskresi dan pelaksanaannya itu ditinjau dari aspek posistifnya adalah merupakan sarana undangundang dan sarana bagi petugas karena tanggungjawab pada tugas-tugasnya.

Kewenangan diskresi Kepolisian sebagai mana Telegram dari Kabareskrim Polri kepada Para Kapolda UP, DIR RESKRIM, Klarifikasi Rahasia, No. TR.1124/XI/2006, tanggal 16 Nopember 2006 tentang Tata Cara Menangani Tindak Pidana Terhadap Anak yang Berhadapan dengan Hukum, antara lain menyatakan bahwa kewe- 
nangan diskresi Kepolisian (Pasal 18 ayat (1) Undang-Undang No. 2 Tahunb2002 tentang Polri) dengan syarat tindakan tersebut benar-benar diperlukan, tindakan yang diambil benarbenar untuk kepentingan tugas Kepolisian, tindakan tersebut adalah tindakan yang tepat untuk mencapai tujuannya/berdasarkan asas keseimbangan yaitu mempertimbangkan sifat perbuatan anak dengan akibat yang ditimbulkannya serta tetap memperhatikan kepentingan terbaik demi tumbuh kembang anak.

Pasal 18 Undang-Undang No. 2 Tahun 2002 menentukan bahwa

(1) Untuk kepentingan umum, pejabat Kepolisian Negara Republik Indonesia dalam melaksanakan tugas dan wewenangnya dapat bertindak menurut penilaiannya sendiri.

(2) Pelaksanaan ketentuan sebagaimana dimaksud dalam ayat (1) hanya dapat dilakukan dalam keadaan yang sangat perlu dengan memperhatikan peraturan perundang-undangan, serta kode Etika Profesi Kepolisian Negara Republik Indonesia.

Rumusan kewenangan Polri dalam Pasal 18 ayat (1) UU Nomor 2 Tahun 2002 tentang Kepolisian Negara Republik Indonesia ini merupakan kewenangan yang bersumber dari asas kewajiban umum Kepolisian yaitu suatu asas yang memberikan kewenangan kepada pejabat Kepolisian untuk bertindak atau tidak bertindak menurut penilaiannya sendiri, dalam rangka kewajiban umumnya guna menjaga, memelihara, ketertiban dan menjamin keamanan umum.

Dalam penjelasan Pasal 18 ayat (1) UU Nomor 2 Tahun 2002 disebutkan bahwa yang dimaksud dengan "bertindak menurut penilaian sendiri" adalah suatu tindakan yang dapat dilakukan oleh anggota Polri yang dalam bertindak harus mempertimbangkan manfaat serta risiko dari tindakannya dan betul-betul untuk kepentingan umum. Secara umum, kewenangan ini dikenal sebagai "Diskresi Kepolisian" yang keabsahannya didasarkan pada pertimbangan keperluannya untuk pelaksanaan tugas dan kewajiban. ${ }^{12}$

\footnotetext{
${ }^{12}$ Pudi Rahardi, 2007. op. cit. hlm. 98
}

Tindakan penyidikan merupakan tindakan yang bersifat penal, dan merupakan bagian awal dari rangkaian proses peradilan pidana dalam rangka penanggulangan kejahatan. Di samping itu Kepolisian dalam upaya penanggulangan kejahatan dapat pula menempuh dengan cara non penal. Dalam tindakan non penal ini meskipun polisi bertindak seolah-oleh justru tidak berdasarkan hukum positif yang berlaku, namun apabila dikaji lebih jauh justru itu suatu tindakan yang dapat menjunjung tinggi tujuan hukum itu sendiri yaitu perlindungan terhadap setiap warga negara. Sementara itu pada tujuan yang lebih jauh dari penegakan hukum pidana yaitu menanggulangi kejahatan, penggunaan peraturan hukum bukan satu-satunya. Menurut Louis A Redelet yang dikutip oleh Roeslan Saleh, Law is not an end in itself, properly understood, it is a mean to higher ends in human affair, much as good order, justice .... ${ }^{13}$

Sehubungan dengan hal tersebut di atas, Polres Purbalingga terkait dengan implementasi UU No. 3 Tahun 1997 terhadap anak yang berhadapan dengan hukum dalam tingkat penyidikan, maka kepolisian bisa melakukan diversi yang merupakan sebuah sistem yang memberikan kesempatan yang baik bagi para pelaku kejahatan ringan yang baru pertama kali menjalankan aksinya, dibanding dengan pemberian hukuman berupa kurungan. Dengan adanya program ini maka masyarakat juga dapat turut berperan dalam memantau perkembangan diri si pelaku serta kembali menerima sebagai warga yang baik. ${ }^{14}$

Dikemukakan oleh Setya Wahyudi, diversi adalah suatu pengalihan penyimpangan pemeriksaan terhadap pelaku anak, yaitu demi perlindaungan anak maka kasus perkara anak dapat dihentikan setiap saat dalam seemua tahapan pemeriksaan (tahap penyidikan, tahap penuntutan, tahap pemeriksaan pengadilan, dan tahap pelaksanaan putusan pengadilan). Apabila terapat anak dikenakan diversi maka ia tidak di proses lebih lanjut dalam sistem

\footnotetext{
${ }^{13}$ Roeslan Saleh, 1995 Kapita Selekta Hukum Pidana, Makalah Kuliah Program S2 Ilmu Hukum Undip, Semarang.

${ }^{14}$ Setya Wahyudi, 2009. op. cit. hlm. 58
} 
peradilan pidana anak, dan terhadap anak tersebut dialihkan dalam berbagai kemungkinan untuk tindakan atau program seperti: penyerahan kepada orang tua/wali; pembinaan sosial; pemberian peringatan/nasihat/konseling.

Dengan batasan tersebut, maka hal-hal yang terdapat dalam ide diversi yaitu, pertama, ide diversi dilakukan demi atau menekankan untuk kepentingan perlindungan anak; kedua, perkara anak tersebut dapat dihentikan dalam tahap penyidikan, penuntutan, pemeriksaan, sehingga terhadap anak tersebut tidak dilakukan penuntutan, dihentikan ketika pemeriksaan pengadilan sehingga tidak dipidana dan atau setelah diputus pidana tetapi pidananya tidak dijalankan; ketiga, terhadap anak tersebut dapat diserahkan kembali kepada orang tua/walinya; keempat, terhadap anak tersebut dapat diberi peringatan, nasihat, konseling atau pembinaan sosial lainnya; dan kelima, terhadap anak dapat dibebani denda ataupun memberi ganti rugi kepada korban. ${ }^{15}$

Dengan berpedoman pada arahan yang terdapat dalam Telegram dari Kaabareskrim Polri, keepada para Kapolda UP. DIR RESKRIM Klarifiasi Rahasia, No. Pol.: TR/1124/XI/2006, tanggal 16 Nopember 2006 tentang Tata Cara Menangani Tindak Pidana Terhadap Anak yang Berhadapan dengan Hukum, maka prinsip diversi harus diupayakan untuk ditetapkan dalam menangani permasalahan hukum anak yang dilaksanakan dengan penuh tanggung jawab. Telegram yang bersifat arahan ini untuk di pedomani dalam pelaksanaanya serta KA bertanggung jawab untuk mendistribusikan, mensosialisasikan, menginternalisaikan pemahaman konsep diversi kepada seluruh anggota sesui fungsi dan perannya dalam jajaran KA hingga ke lini terdepan.

Prinsip diversi yang terdapat dalam konvensi hak-hak anak yaitu suatu pengalihan bentuk penyelesaian dari penyelesaian yang bersifat pidana formal ke alternatif penyelesaian dalam bentuk lain yang dinilai terbaik demi kepentingan anak. Diversi dapat dalam bentuk dikembalikan ke orang tua si anak baik

\footnotetext{
${ }^{15}$ Ibid., hlm. 80
}

tanpa maupun disertai peringatan informal/formal, mediasi, musyawarah kelompok keluarga pelaku dan keluarga korban, atau bentukbentuk penyelesaian terbaik lainnya yang sesuai dengan budaya masyarakat setempat. Peringatan informal adalah pemberian peringatan disertai penjelasan tentang dampak buruk dari perbuatan anak baik bagi korban maupun orang lain dan menasihati serta memperingatkan si anak agar tidak melakukannya lagi. Perlindungan formal adalah peringatan informal yang diberikan kepada anak baik secara tertulis atau lisan di depan orang tuanya si anak. Diversi dalam bentuk mediasi adalah tindakan polisi menjadi perantara guna mengkomunikasikan atau memfasilitasi pemenuhan kebutuhan korban dan perlindungan terhadap anak sebagai pelaku dalam bingkai tujuan menyelesaikan persoalan yang timbul akibat perbuatan pelaku anak. Musyawarah kelompok adalah pertemuan antara anak sebagai pelaku dengan semua pihak yang telah dirugikan oleh tindakan si anak untuk secara bersama-sama memutuskan hal-hal yang harus dilakukan untuk memperbaiki kesalahannya dan mencegah terulangnya perbuatan serupa di kemudian hari, sementara Polisi tetap berperan sebagai fasilitator.

Dasar hukum penerapan adalah Pasal 16 ayat (1) huruf L Undang-undang No. 2 Tahun 2002 tentang Polri yang berbunyi mengadakan tindakan lain menurut hukum yang bertanggung jawab dengan batasan bahwa tindakan tersebut tidak bertentangan degan hukum yang berlaku, selaras dengan kewajiban hukum/profesi yang mengharuskan dilakukannya tindakan jabatan tersebut, tindakan tersebut harus patut dan masuk akal dan termasuk dalam lingkup jabatannya, didasarkan pada pertimbangan yang layak berdasarkan keadaan yang memaksa dan menghormati Hak Asas Manusia.

Sedapat mungkin mengembangkan prinsip diversi dalam model Restorative Justice guna memproses perkara pidana yang dilakukan oleh anak dengan membangun/pemahaman dalam komunitas setempat bahwa keterlibatan anak dalam tindak pidana harus dipahami sebagai kenakalan anak akibat kegagalan/kesalahan 
orang dewasa dalam mendidik dan mengawal anak sampai usia dewasa. Tindak pidana anak harus dipandang sebagai pelanggaran terhadap manusia dan relasi antar manusia sehingga memunculkan kewajiban dari semua pihak/seluruh komponen masyarakat untuk terus berusaha dan membuat segala sesuatunya menjadi lebih baik melalui pelibatan semua pihak untuk ambil peran guna mencari solusi terbaik, baik untuk kepentingan pihak-pihak yang menjadi korban dan bagi kepentingan anak sebagai pelaku di masa sekarang dan masa yang akan datang. Cara demikian diharapkan setiap tindak pidana yang melibatkan anak dapat diproses dengan pendekatan Restorative Justice sehingga menjauhkan anak dari proses hukum formal/pengadilan agar anak terhindar dari trauma psikologis dan stigmasasi serta dampak buruk lainnya sebagai ekses penegakan hukum formal/pengadilan. Penahanan terhadap anak hanya dilakukan ketika sudah tidak ada jalan lain dan merupakan langkah terakhir (ultimatum remedium), dan pelaksanaannya harus dipisahkan dari tahanan dewasa.

Dikemukakan oleh Aniek Periani, bahwa konsep Restorative Justice sebagai alternatif penyelesaian perkara pidana dengan pelaku anak. Restorative Justice sebagai suatu proses semua pihak yang berhubungan dengan tindak pidana tertentu duduk bersama-sama untuk memecahkan masalah dan memikirkan bagaimana mengatasi akibat di masa yang akan datang. Proses Restorative Justice pada dasarnya dilakukan melalui diskresi (kebijaksanan) dan diversi, yaitu membuat peraturan dari bentuk penyimpangan penanganan anak nakal di luar jalur yustisial konvensional atau pengalihan dari proses peradilan pidana keluar dari pross formal untuk diselesaikan secara musyawarah, sebagaimana dikehendaki dalam Commentary Rule 11 Resolusi PBB 40/33. ${ }^{16}$

Jika kita melihat pada ketentuan UndangUndang Pengadilan Anak, Aniek Periani, berpendapat bahwa ketentuan ius constitutum mengenai Pengadilan Anak saat ini tidak efektif sebagaimana digariskan pada konsideran dan

\footnotetext{
${ }^{16}$ Aniek Periani, 2008. op. cit. hlm. 23
}

penjelasan UUPA itu sendiri, karena UUPA tidak memberikan ruang dan jalan keluar untuk melakukan diskresi dan diversi kepada hakim setelah melihat penilaian BAPAS. Padahal diskresi dan diversi merupakan klep pengaman bagi anak-anak pelaku kejahatan tertentu, untuk terhindar dari proses konvensional sistem peradilan pidana anak yang lazimnya memiliki dampak negatif terhadap terjadinya stigmatisasi anak, di mana stigmatisasi yang dialami oleh anak dalam kajian kriminologi menjadi faktor pemicu kriminogen dalam menanggulangi kenakalan berikutnya. Sebaliknya pada tatanan ius operatum, ketentuan Undang-Undang No. 3 Tahun 1997, penegakan hukumnya belum mampu dilakukan oleh aparat penegak hukum yang profesional membidangi anak sebagaimana dikehendaki undang-undang itu sendiri. ${ }^{17}$

Dengan menggunakan konsep Restorative Justice hasil yang diharapkan adalah berkurangnya jumlah anak-anak yang ditangkap, ditahan, dan di vonis penjara, menghapuskan stigma/ cap dan mengembalikan anak menjadi manusia normal sehingga diharapkan dapat berguna kelak di kemudian hari; pelaku pidana anak dapat menyadari kesalahannya, sehingga tidak mengulangi perbuatannya, mengurangi beban kerja Polisi, Jaksa, Rutan Pengadilan, dan Lapas; menghemat keuangan negara, tidak menimbulkan rasa dendam karena pelaku telah dimaafkan oleh korban; korban cepat mendapat ganti kerugian; membudayakan orang tua dan masyarakat dalam mengatasi kenakalan anak; pengintegrasian kembali anak ke dalam masyarakat. Adapun sebagai mediator dalam musyawarah dapat diambil dari tokoh masyarakat yang dipercaya dan bila kejadiannya di sekolah, dapat dilakukan kepada sekolah atau guru.

Syarat utama dari penyelesaian melalui musyawarah pemulihan adalah adanya pengakuan dari pelaku serta adanya persetujuan dari pelaku beserta keluarganya dan korban untuk menyelesaikan perkara melalui musyawarah pemulihan. Jadi musyawarah tidak boleh didasarkan atas paksaan. Apabila pihak-pihak tidak menghendaki penyelesaian melalui musyawarah

\footnotetext{
${ }^{17}$ Ibid., hlm. 24
} 
pemulihan, maka proses peradilan baru berjalan. ${ }^{18}$

Ada beberapa kriteria perkara pidana yang melibatkan anak sebagai pelaku yang harus diupayakan penyelesaiannya dengan pendekatan prinsip diversi. Pertama, kategori tindak pidana yang diancam dengan sanksi pidana sampai dengan satu tahun harus diprioritaskan untuk diterapkan diversi, tindak pidana yang diancam dengan sanksi pidana di atas satu tahun sampai dengan lima tahun dapat dipertimbangkan untuk penerapan diversi, semua kasus pencurian harus diupayakan penerapan diversi kecuali menyebabkan timbul kerugian yang terkait dengan tubuh dan jiwa.

Kedua, memperhatikan usia pelaku, semakin muda usia pelaku maka urgenitas penerapan prinsip diversi semakin diperlukan; ketiga, hasil penelitian masyarakat dari BAPAS, bila ditemukan faktor pendorong anak terlibat dalam kasus pidana adalah faktor yang ada di luar kendali anak maka urgenitas penerapan prinsip diversi semakin diperlukan; keempat, kerugian yang ditimbulkan oleh tindak pidana anak, bila akibat yang ditimbulkan bersifat kebendaan dan tidak terkait dengan tubuh dan nyawa sesorang maka urgenitas penerapan diversi semakin diperlukan.

Kelima, tingkat keresahan masyarakat yang diakibatkan oleh perbuatan anak; keenam, dukungan lingkungan keluarga baik dari korban maupun pelaku serta masyarakat di sekitar tindak kejadian perkara anak bertempat tinggal; ketujuh, persetujuan korban/keluarga; kedelapan, kesediaan pelaku dan keluarganya; dan kesembilan, dalam hal melakukan tindak pidana bersama-sama orang dewasa maka orang dewasa harus diproses hukum sesuai prosedur biasa.

Dalam penanganan terhadap anak yang berhadapan dengan hukum baik sebagai pelaku maupun sebagai saksi/korban Polisi harus mempedomi peraturan perundang-undangan (Undang-Undang No. 4 Tahun 1979 tentang Kesejahteraan Anak; Undang-Undang No. 3 Tahun 1997 tentang Pengadilan Anak; Undang-Undang

\footnotetext{
${ }^{18}$ Loc. cit
}

No. 23 Tahun 2002 tentang Perlindungan Anak; Undang-Undang No. 2 Tahun 2002 tentang Polri; Peraturan Pemerintah No. 2 Tahun 2003 tentang Peraturan Disiplin Anggota Polri; Telegram Kabareskrim Polri No. Pol: TR/1124/XI/2006 tanggal 16 Nopember 2006 tentang Tata Cara Menangani Tindak Pidana Terhadap Anak Yang Berhadapan Dengan Hukum; Telegram Kabareskrim Polri No. Pol.: TR/395/DIT-I/VI/2008 tanggal 9 Juni 2008 tentang Cara Penyidikan Tehadap Anak yang Berhadapan dengan Hukum.

Dalam Telegram Kabareskrim Polri No. Pol.: TR/395/DIT-I/VI/2008 tanggal 9 Juni 2008 tentang Cara Penyidikan Tehadap Anak yang Berhadapan dengan Hukum, disebutkan bahwa untuk menghindari kesalahan dalam proses penyidikan terhadap $A B H$, agar mempedomi beberapa hal. Pertama, pemanggilan terhadap ABH agar dilampirkan surat pengantar kepada orang tua/wali supaya menghadapkan anaknya kepada penyidik; kedua, penangkapan terhadap $\mathrm{ABH}$ merupakan upaya terakhir kecuali $\mathrm{ABH}$ sebagai pelaku tindak pidana berat dengan mempedomani ketentuan penangkapan yang berlaku dengan memperhatikan kepentingan terbaik anak.

Ketiga, pemeriksaan terhadap $\mathrm{ABH}$ menggunakan metode wawancara dalam suasana kekeluargaan dengan materi yang sudah di siapkan untuk mendapatkan data/keterangan yang diharapkan, didampingi penasihat hukum, pendamping yang disetujui $A B H$, menggunakan alat perekam, keterangan $\mathrm{ABH}$ dituangkan dalam Berita Acara Pemeriksaan dan ditandatangani apabila $\mathrm{ABH}$ telah setuju; keempat, penahananan merupakan upaya terakhir apabila $A B H$ diduga sebagai pelaku tindak pidana berat dengan usia di atas 8 tahun, bila terpaksa harus ditahan harus dipisahkan dengan tahanan dewasa serta waktu penahanan maksimal 20 hari dan dapat diperpanjang oleh Jaksa Penuntut Umum maksimal 10 hari; dan kelima, meminta pertimbangan BAPAS untuk melaksanakan penelitian kemasyarakatan (Litmas) terhadap $\mathrm{ABH}$, Apabila diperlukan, melibatkan psikolog untuk memeriksa kejiwaan $\mathrm{ABH}$ tersebut.

Pembedaan perlakuan dan ancaman yang diatur dalam UU No. 3 Tahun 1997 dimaksudkan 
untuk lebih melindungi dan mengayomi anak agar dapat menyongsong masa depannya yang masih panjang. Memberikan kesempatan kepada anak agar melalui pembinaan akan di peroleh jati dirinya untuk menjadi manusia yang mandiri, bertanggung jawab, dan berguna bagi diri, keluarga, masyarakat, bangsa dan negara.

Dengan demikian berdasarkan pembahasan terhadap hasil penelitian tersebut di atas dapat diketahui bahwa implementasi Undangundang No. 3 Tahun 1997 terhadap anak yang berhadapan dengan hukum dalam tingkat penyidikan di Polres Purbalingga pada dasarnya dilakukan melalui pendekatan penal dan non penal.

Faktor-faktor yang menghambat implementasi UU No. 3 Tahun 1997 terhadap anak yang berhadapan dengan hukum dalam tingkat penyidikan di Polres Purbalingga

Lahirnya Undang-Undang Nomor 2 Tahun 2002 tentang Kepolisian Negara Republik Indonesia, mebuat tegas pembatasan tugas dan wewenang Kepolisian. Pembatasan tugas dan wewenang Kepolisian sebagai salah satu pemegang fungsi pemerintahan negara khususnya dibidang pemeliharaan kemanan dan ketertiban masyarakat, penegak hukum, perlindungan, pengayoman, dan pelayan masyarakat.

Sehubungan dengan masalah faktor-faktor yang menghambat implementasi Undangundang No. 3 Tahun 1997 terhadap anak yang berhadapan dengan hukum dalam tingkat penyidikan di Polres Purbalingga, Dikemukakan oleh Soerjono Soekanto bahwa pada pokoknya masalah tersebut sebenarnya terletak pada faktor-faktor yang mungkin mempengaruhinya. Faktor-faktor tersebut mempunyai arti yang netral, sehingga dampak positif atau negatifnya terletak pada isi faktor-faktor tersebut.

Adapun faktor-faktor dimaksud, anatara lain sebagai berikut. Pertama, faktor hukumnya sendiri, yang di dalam tulisan ini akan di batasi pada Undang-undang saja; kedua, faktor penegak hukum, yakni fihak-fihak yang membentuk maupun menerapkan hukum; ketiga, faktor sarana atau fasilitas yang mendukung penegakan hukum; keempat, faktor masyarakat, yakni lingkungan di mana hukum tersebut berlaku atau diterapkan; dan kelima, faktor kebudayaan, yakni sebagai hasil karya, cipta dan rasa yang didasarkan pada karsa manusia di dalam pergaulan hidup.

Kelima faktor tersebut di atas saling berkaitan dengan eratnya, oleh karena merupakan esensi dari penegakan hukum, serta juga merupakan tolok ukur dari pada efektivitas penegakan hukum. ${ }^{19}$

Mendasarkan pada pendapat Soerjono Soekanto di atas, maka berdasarkan hasil penelitian diperoleh data bahwa faktor-faktor yang menghambat implementasi UU No. 3 Tahun 1997 terhadap anak yang berhadapan dengan hukum dalam tingkat penyidikan di Polres Purbalingga, dapat diuraikan sebagai berikut.

\section{Faktor hukumnya sendiri}

Persoalan tentang peraturan hukum positif yang diterapkan di lapangan berkaitan dengan tuntutan atau kepentingan tugas atau pengembangan kehidupan bermasyarakat, agar hukum itu dapat hidup di tengah masyarakat, maka dibutuhkan peraturan hukum formal yang dipandang lebih efektif dan dirasakan keadilannya oleh masyarakat.

Terkait dengan kelemahan yang dijumpai dalam peraturan perundang-undangan dan berpengaruh terhadap penegakan hukum atas ketentuan hukum tersebut, Ka. BAPAS Purwokerto mengemukakan bahwa peraturan perundangundangan yang dibuat terkadang masih kurang memperhatikan aspek-aspek perkembangan yang bersifat global, kurangnya perhatian para pembentuk undang-undang di dalam hal penelusuran peraturan perundang-undangan, di mana sering pula ditemukan adanya ketidak sinkronan antara undang-undang yang satu dengan yang lain yang sejenis. Di samping itu masih adanya pola pemikiran dari pembuat undangundang yang berasumsi bahwa dengan dibuatnya suatu undang-undang setiap permasalahan

\footnotetext{
${ }^{19}$ Soerjono Soekanto, 1993. op. cit. hlm. 6.
} 
yang ada dalam masyarakat sudah dapat di atasi. ${ }^{20}$

Implementasi UU No. 3 Tahun 1997 terhadap anak yang berhadapan dengan hukum dalam tingkat penyidikan, dalam praktik penegakan hukum, peraturan hukum memberikan kewenangan pada polisi untuk melakukan tindakan-tindakan tertentu, namun demikian dalam menjalankan tugasnya, polisi tidak mungkin bertindak secara kaku. Ada beberapa hal menurut pendapat Faal mengenai alasan polisi bertindak demikian. Pertama, tidak ada perundang-undangan yang demikian lengkapnya, sehingga dapat mengatur semua perilaku manusia; kedua, adanya hambatan-hambatan untuk menyesuaikan perundang-undangan dengan perkembangan-perkembangan di dalam masyarakat sehingga menimbulkan ketidakpastian; ketiga, kurangnya biaya untuk menerapkan perundang-undangan sebagaimana yang dikehendaki oleh pembentuk undang-undang; dan ketiga, adanya kasus-kasus individual yang memerlukan penanganan secara khusus. ${ }^{21}$

Peraturan perundang-undangan yang di terapkan untuk memproses perkara-perkara terhadap anak yang berhadapan dengan hukum yang ada sekarang dan masih berlaku, dianggap masih relevan dan memenuhi asas memberi efek jera sekaligus memiliki efek pembinaan. Dengan demikian dalam kaitan ini faktor hukumnya tidak berpengaruh terhadap penegakan hukum dalam proses penyidikan anak yang berhadapan dengan hukum.

\section{Faktor Penegak Hukum}

Kanit Perlindungan Perempuan dan Anak Polres Purbalingga AIPTU Endang Iswarani, SH, mengemukakan adanya hambatan dalam melakukan proses penyidikan terhadap anak yang berhadapan dengan hukum, yaitu penyidik dalam melakukan penyidikan masih ditemukan adanya personil penyidik khusus anak dan kemampuan profesionalisme di bidang penyidikan dalam melakukan penyidikan terhadap anak yang berhadapan dengan hukum, belum

\footnotetext{
${ }^{20}$ Wawancara dengan Supriyono, Bc.IP, S.H. selaku Ka. BAPAS Purwokerto, 3 September 2009

${ }^{21}$ Faal, 1991. op. cit. hlm. 101.
}

sepenuhnya memahami apa yang telah di amanatkan oleh undang-undang yang berkaitan dengan $\mathrm{ABH} .{ }^{22}$

Faktor penegak hukum yang dianggap masih menghambat pelaksanaan penanganan anak yang bermasalah dengan hukum hal ini seperti dikemukakan oleh Supriyono, Bc. IB.SH, yang menyatakan bahwa dalam tahapan proses hukum terhadap $\mathrm{ABH}$ telah dilaksanakan sesuai dengan proses hukum yang berlaku. Namun belum sepenuhnya mengutamakan aspek perlindungan hak anak, dan kesejahteraan anak dalam setiap kasus $\mathrm{ABH} .{ }^{23}$

Selain hambatan sebagaimana tersebut di atas, Supriyono, Bc. IB.SH selaku Ka. BAPAS Purwokerto menyatakan bahwa petugas Pembimbing Kemasyarakatan (PK) BAPAS yang bertugas melaksanakan penelitian kemasyarakatan dan pembimbingan klien tidak semua petugas PK mendapat kesempatan untuk mengikuti Diklat tentang Pembimbing Kemasyarakatan. ${ }^{24}$

Terkait dengan hak-hak anak serta hakikat kebutuhan anak dan masyarakat tersebut, Supriyono, BC. IB.SH mengemukakan bahwa tidak selalu ada persamaan perspektif dalam pembelaan hak-hak anak dan dalam pendekatan untuk pembimbingan dan model rehabilitasi perilaku menyimpang kenakalan anak, sehingga sering saran Pembimbing Kemasyarakatan (PK) BAPAS, untuk putusan non pidana, tidak diperhatikan oleh hakim. ${ }^{25}$

\section{Faktor Sarana atau Fasilitas yang mendukung penegakan hukum.}

Faktor sarana atau fasilitas yang menjadi penghambat dalam proses penyidikan terhadap anak yang berhadapan dengan hukum adalah Sarana dan prasarana untuk memperlancar tugas-tugas kepolisian Polres Purbalingga adalah belum sepenuhnya dicukupi bentuk pelayanan/penyidikan terhadap ABH dalam rangka meningkatkan pelayanan secara optimal untuk me-

\footnotetext{
${ }^{22}$ Wawancara dengan AIPTU Endang Iswarani, SH, selaku Kanit PPA di Polres Purbalingga, 9 Desember 2009

${ }^{23}$ Wawancara dengan Supriyono, Bc.IP, S.H. selaku Ka. BAPAS Purwokerto, 3 September 2009

${ }^{24}$ Ibid

25 Ibid.
} 
lakukan penyidikan terhadap anak, khususnya dalam masalah pelayanan, yang dapat dikemukakan adalah Polres tidak menyediakan pakaian khusus untuk tahanan anak.

\section{Faktor Masyarakat, yakni lingkungan di mana} hukum tersebut berlaku atau diterapkan

Sehubungan dengan faktor masyarakat yang ikut mempengaruhi penegakan hukum ini, apabila dikaitkan dengan pendapat Friedman tentang unsur-unsur dalam sistem hukum yang salah satu unsurnya adalah "budaya hukum" yaitu sikap-sikap dan nilai yang berhubungan dengan hukum, yang datangnya dari rakyat atau pemakai jasa hukum, ${ }^{26}$ maka dapat di kemukakan bahwa budaya hukum masyarakat yang dicerminkan dapat dilihat dari jenis dan jumlah kasus yang penyebab utamanya antara lain disebabkan oleh pengaruh pergaulan, lingkungan dan media. Pengaruh lain yang menjadi penyebab anak berhadapan dengan hukum adalah dari faktor tekanan ekonomi dan kejiwaan. Hal ini dapat dikatakan bahwa faktor masyarakat khususnya budaya hukum masyarakat meerupakan faktor penghambat dalam perkara anak yang berhadapan dengan hukum.

Dalam proses penyidikan terhadap anak yang berhadapan dengan hukum di Polres Purbalingga, pihak terlapor merasa takut apabila berhadapan dengan polisi/penyidik sehingga dalam memberikan keterangan yang berkaitan dengan perbuatan tersangka agak berbelit-belit/belum transparan untuk mengatakan fakta yang sebenarnya, orang tua korban/terlapor masih menunjukan sifat mau menang sendiri merasa bahwa anaknya adalah yang benar. ${ }^{27}$

Pada umunya masyarakat belum mengetahui tentang penanganan terhadap anak yang melakukan tindak pidana belum banyak masyarakat yang mengerti tentang peraturan undangundang yang berhubungan dengan anak dan aturannya, masyarakat kurang peduli pada lingkungan dan cenderung untuk memvonis ter-

\footnotetext{
26 Abdul Manan, 2005. op. cit. hlm. 9.

27 Wawancara dengan AIPTU Endang Iswarani, SH, selaku Kanit PPA di Polres Purbalingga, 9 Desember 2009
}

hadap perbuatan yang dilakukan oleh tersangka bahwa pelaku kejahatan itu harus dihukum. ${ }^{28}$

Berdasarkan uraian sebagaimana tersebut di atas, yaitu tentang faktor yang menghambat implementasi UU No. 3 Tahun 1997 terhadap anak yang berhadapan dengan hukum dalam tingkat penyidikan di Polres Purbalingga, apabila dihubungkan dengan hasil penelitian dapat dijelaskan bahwa faktor-faktor dimaksud.

Pertama, hambatan dari faktor penegak hukum, masih belum ada persamaan perspektif dalam penanganan terhadap anak yang berhadapan dengan hukum di antara para penegak hukum. Personil penyidik khusus anak dalam melakukan penyidikan terhadap anak yang berhadapan dengan hukum, belum sepenuhnya memahami apa yang telah diamanatkan oleh undang-undang yang berkaitan dengan $\mathrm{ABH}$.

Kedua, hambatan dari faktor sarana atau fasilitas yang menjadi penggambat dalam proses penyidikan terhadap anak yang berhadapan dengan hukum adalah Sarana dan prasarana untuk memperlancar tugas-tugas kepolisian adalah belum sepenuhnya dicukupi bentuk pelayanan/penyidikan terhadap $\mathrm{ABH}$ dalam rangka meningkatkan pelayanan secara optimal untuk melakukan penyidikan terhadap anak khususnya dalam masalah pelayanan, Polres tidak menyediakan pakaian khusus untuk tahanan anak.

Ketiga, hambatan dari faktor masyarakat, yaitu banyak masyarakat yang belum mengerti tentang peraturan undang-undang yang berhubungan dengan anak dan aturannya, masyarakat kurang peduli pada lingkungan dan cenderung untuk memvonis perbuatan yang di lakukan oleh tersangka anak seperti terhadap tersangka orang dewasa.

\section{Penutup \\ Simpulan}

Beberapa simpulan yang dapat dikemukakan atas permasalahan yang telah dibahas adalah sebagai berikut. Pertama, Polres Purbalingga telah mengedepankan azas kepentingan terbaik anak sebagai landasan utama dalam

\footnotetext{
${ }^{28}$ Ibid.
} 
mengambil keputusan tentang pola penanganan terhadap perkara yang melibatkan anak dan dalam menangani kasus yang melibatkan anak sebagai pelaku penyidik terus berusaha mencari alternatif penyelesaian terbaik bagi kepentingan tumbuh kembang anak serta seoptimal mungkin berupaya menjauhkan anak dari proses peradilan formal/pengadilan. Penanganan terhadap anak yang berhadapan dengan hukum dalam tingkat penyidikan pada dasarnya sudah dilaksanakan secara optimal sesuai dengan peraturan perundang-undangan yang berlaku, baik melalui pendekatan penal maupun non penal. Pendekatan non penal antara lain di lakukan dengan diversi dan model Restorative Justice. Penerapan program diversi dimaksudkan untuk menghilangkan efek negatif, yang timbul dari penerapan prosedur formil, maupun administratif dan menggantikannya dengan suatu kebijakan yang berbasis pelayanan sosial kemasyarakatan. Penegak hukum dalam mengambil tindakan kebijakan terhadap anak yang berhadapan dengan hukum antara lain menghentikan proses peradilan pidana dengan mengembalikan kepada masyarakat dan bentuk kegiatan pelayanan sosial lainnya.

Kedua, hambatan yang ada pada implementasi UU No. 3 Tahun 1997 adalah hambatan dari faktor penegak hukum, masih belum ada persamaan perspektif dalam penanganan terhadap anak yang berhadapan dengan hukum di antara para penegak hukum; hambatan dari faktor sarana atau fasilitas adalah belum sepenuhnya dicukupi bentuk pelayanan/penyidikan terhadap $\mathrm{ABH}$ dalam rangka meningkatkan pelayanan secara optimal untuk melakukan penyidikan terhadap anak khususnya dalam masalah pelayanan; dan hambatan dari faktor masyarakat, yaitu banyak masyarakat yang belum mengerti tentang peraturan undang-undang yang berhubungan dengan anak dan aturannya, masyarakat kurang peduli pada lingkungan dan cenderung untuk memvonis perbuatan yang dilakukan oleh tersangka anak seperti terhadap tersangka orang dewasa.

\section{Saran}

Pembentukan undang-undang harus selalu berpijak kepada nilai-nilai sosial kultur masyarakat yang diharapkan dapat mengatasi masalah anak yang berhadapan dengan hukum tidak menimbulkan permasalahan baru. Fihak-fihak yang menerapkan hukum diharapkan selalu berkoordinasi, untuk menciptakan konstruksi kesamaan kehendak dalam rangka membangun pemahaman dan persepsi yang sama terhadap penanganan penyidikan anak yang harus mengedepankan asas kepentingan terbaik anak. Demikian pula prinsip penanganan secara diversi harus diupayakan untuk ditetapkan dalam menangani permasalahan hukum anak yang di laksanakan dengan penuh tanggung jawab. Perlu dibentuk penyidik khusus anak yang profesional, proporsonal, empati dan transparan berkepribadian mencintai dan menyayangi anak dengan mendapatkan bekal pengetahuan tentang peraturan perundang-undangan yang berkaitan dengan anak. 